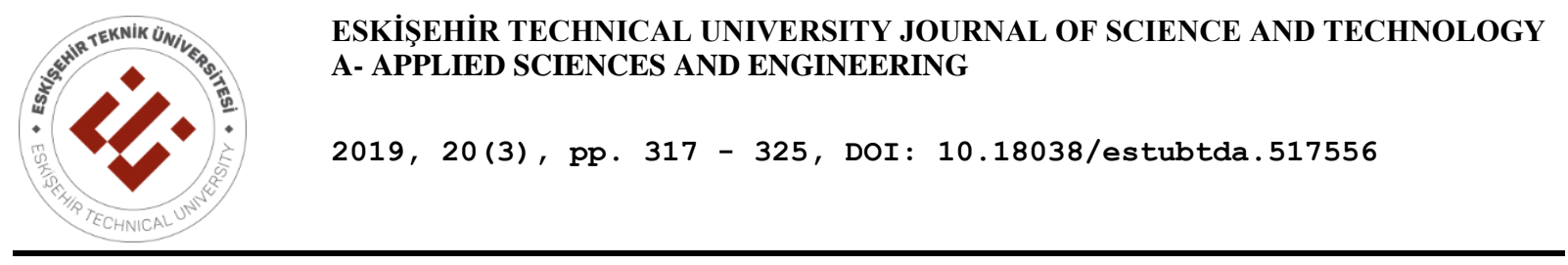

\title{
PARTICULATE MATTER FORMATION DURING CO-COMBUSTION OF AGRICULTURAL RESIDUES WITH TURKISH LIGNITE USING A DROP TUBE FURNACE
}

\author{
Feyza KAZANÇ ÖZERİNÇ*
}

Department of Mechanical Engineering, Faculty of Engineering, Middle East Technical University, Ankara, Turkey

\begin{abstract}
This study investigates the particulate matter formation during combustion of olive residue, almond shell, and Tunçbilek lignite. Selected fuels (olive residue and Tunçbilek lignite) were also co-fired to evaluate the influence on particulate matter emission. Olive residue was ground to different size ranges $(<125 \mu \mathrm{m}$ and $212-300 \mu \mathrm{m})$ to investigate the influence of the particle size and blended in different ratios of biomass / coal to analyse the interactions between fuels. Tests were performed in a drop tube furnace at high temperature $\left(1000^{\circ} \mathrm{C}\right)$, with a high heating rate $\left(\sim 10^{4}{ }^{\circ} \mathrm{C} / \mathrm{s}\right)$, and short residence time $(\sim 3 \mathrm{~s})$. Fuel was fed into the furnace at a low mass rate of $10 \mathrm{~g} / \mathrm{h}$ using a syringe pump. Particulate matter was collected using a 3-stage stack impactor and categorized according to the aerodynamic diameters, PM2.5, PM2.5-10, and PM10. The results obtained included particle burnout, and particulate matter concentration. Particle burnout was above $95 \%$ for all studied fuels. Particulate matter emission depended greatly on the fuel and the blend. Olive residue presented the lowest values of PM2.5 (176 mg/g ash in fuel fed) compared with both almond shell (214 mg/g ash in fuel fed) and Tunçbilek lignite (286 mg/g ash in fuel fed). PM10 emission was particularly low for olive residue $(\sim 200 \mathrm{mg} / \mathrm{g}$ ash in fuel fed), whereas almond shell and Tunçbilek lignite showed similar values ( $400 \mathrm{mg} / \mathrm{g}$ ash in fuel fed). Larger biomass particles resulted in unchanged particulate matter emissions. Co-firing of the olive residue with the Tunçbilek lignite resulted in lower PM2.5 (as compared to neat olive); higher PM2.5-10 (as compared to neat lignite); and lower PM10 (as compared to lignite). Blends of OR-TL in 25-75 ratio showed lower values of both PM2.5 and PM10 as compared with the 50-50 blends of the same fuels.
\end{abstract}

Keywords: Turkish lignite, Biomass, Co-firing, particulate matter, Drop tube furnace

\section{INTRODUCTION}

In Turkey, large reserves of indigenous lignite (15.6 billion tonnes) combined with an effort to decrease the energy dependence on imported fossil fuels have generated widespread incentives to increase the total installed capacity of lignite power plants three-fold by 2023 [1]. The burning of lignite coal presents several issues that require investigation such as the emission of pollutants $\left(\mathrm{CO}_{2}, \mathrm{NO}_{\mathrm{x}}, \mathrm{SO}_{\mathrm{x}}\right)$, particulate matter, slagging, and fouling. Particulate matter (PM) emission has contributed to an estimated 3.2 million premature deaths as a consequence of cardiovascular diseases and lung cancer [3]. Therefore, there is a need for further research on the formation of particulate matter in order to minimize its formation and design equipment suitable to capture PM.

The growing number of coal-biomass co-fired power plants [4] also raises concerns since studies on coal-biomass combustion with an emphasis on PM formation are still scarce. Some initial studies suggest that emission of submicron PM from biomass may be higher as compared to coal [5], and there are, additional concerns that the biomass-PM may interfere with the coal-PM precipitators. On the other hand, despite the high economic potential of 32.6 Mton per year, only about $0.1 \%$ of the electricity generation in Turkey was biomas-based in 2012, showing the great potential of co-firing for improving the efficiency of power generation [2].

For both coal [6-8] and biomass [9], the two main mechanisms of PM formation are (i) the solid particle pathway during which the excluded mineral matter is directly converted into coarse PM, and (ii) the

*Corresponding Author: fkazanc@metu.edu.tr

Received: 24.01.2019 Published: 26.09.2019 
vaporization of mineral matter followed by conversion into fine PM during condensation. PM formation is therefore strongly dependent on the mineral content (included and/or excluded) $[8,10]$, and on the fragmentation of char/ash particles at high temperatures [11,12]. Moreover, since coal and biomass typically differ in mineral content, the formation and characteristics of PM is strongly fuel-dependent [10,13-15]. The influence of coal rank on PM formation was investigated by Wen et al. [10] who observed that formation of both submicron and supermicron PM decreased with the increase in coal rank from lignite to coal, and coal to anthracite. Gao et al. [15] investigated mallee wood, bark, and leaf, and observed that the emissions from both bark and leaf were higher when compared to wood. Zellagui et al. [5] studied the co-firing of a woody biomass with different coals, and concluded that a ratio of 25 wt.\% biomass minimized the formation of ultrafine PM0.1 and PM2.5.

In this context, this study investigates the particulate matter emission from the co-combustion of a Turkish lignite with two distinct agricultural residues, olive residue and almond shell, under high temperature and high heating rate conditions using a drop tube furnace.

\section{MATERIALS AND METHODS}

\subsection{Fuel Samples}

Three endogenous resources of Turkey were selected for this study: olive residue (OR), almond shell (AS), and Tunçbilek lignite (TL). Olive residue was supplied by the company Fora Zeytin. This company processes olives from the Havran, Balıkesir region, and delivered the olive residue ground to below $5 \mathrm{~mm}$ diameter and pre-dried to less than $10 \mathrm{wt}$. \% moisture. Almond shell is an agricultural waste of almond production and was supplied as chunks by Bademder (cooperative from the region of Gülnar, Mersin). The lignite coal was supplied by the Turkish Coal Enterprises (TKI) from the mining region of Tunçbilek - Tavşanlı, Kütahya (annual tonnage of $7 \mathrm{Mt}$ ). The results of proximate, and ultimate analyses, inorganic species, and heating values can be found in Table 1. Fuels were first ground to a size smaller than $1 \mathrm{~mm}$ using a roll crusher, and ground further using a ring mill. All ground particles were sieved to a size cut $<125 \mu \mathrm{m}$ and OR was additionally sieved to a larger particle size $(212-300 \mu \mathrm{m})$ to assess the influence of particle size on the PM formation. All samples were dried overnight at around $100^{\circ} \mathrm{C}$ before the combustion trials.

\subsection{Experimental Methods}

The experimental setup is schematically presented in Figure 1. The setup consists of a drop tube furnace, a feeding system, and a collection unit. The drop tube furnace (Protherm PTF 15.75.1000) is an electrically heated furnace with $\mathrm{Si}$ and $\mathrm{MoSi}_{2}$ heating elements that can supply a maximum power of $7.5 \mathrm{~kW}$ and enable a maximum (constant) wall temperature of $1500^{\circ} \mathrm{C}$ measured by an S-type thermocouple placed at the midpoint of the heated zone. An alumina tube $\left(60 \% \mathrm{Al}_{2} \mathrm{O}_{3}\right)$ of $1500 \mathrm{~mm}$ length and $75 \mathrm{~mm}$ inner diameter was used to confine the reaction zone $(1000 \mathrm{~mm})$. The particles were fed from a glass vial by means of a syringe pump (Harvard Apparatus 22). The linear movement of the syringe pump was set to ensure that the distance between the particle bed and the tip of the capillary tube remained at $\sim 3 \mathrm{~mm}$ along time. A $12 \mathrm{~V}$ vibrating motor was used to obtain a well-stirred particle bed, avoiding clogging in the capillary tube. Air was injected into the glass vial to force the particles into the capillary tube. Particles were injected downwards into the reaction zone of the furnace using a capillary tube of $2 \mathrm{~mm}$ inner diameter and a water-cooled injector.

The combustion of the particles in the drop tube furnace took place at a constant wall temperature of $1000^{\circ} \mathrm{C}$, and the heating rate was estimated to be on the order of $10^{4} \mathrm{C} / \mathrm{s}$. The total flow used, primary air + secondary air, was $20 \mathrm{~L} / \mathrm{min}$, which resulted in a residence time of $\sim 3 \mathrm{~s}$ in the isothermal reaction zone. The mass flow of particles was kept low at $10 \pm 1 \mathrm{~g} / \mathrm{h}$ to maintain lean combustion conditions and 
to minimize interactions between particles (e.g. changes in the air-volatile ratio in the vicinity of the particles, or radiative heat exchange between particles).

Table 1. Elemental analysis of the studied samples

\begin{tabular}{|c|c|c|c|}
\hline Parameter & $\begin{array}{l}\text { Olive residue } \\
\text { (OR) }\end{array}$ & $\begin{array}{l}\text { Almond } \\
\text { shell } \\
(\mathrm{AS}) \\
\end{array}$ & $\begin{array}{l}\text { Tunçbilek } \\
\text { lignite } \\
\text { (TL) }\end{array}$ \\
\hline \multicolumn{4}{|c|}{ Proximate analysis, wt.\% as received } \\
\hline Moisture & 5.9 & 8.5 & 2.81 \\
\hline Volatiles & 71.9 & 73.0 & 31.1 \\
\hline Fixed carbon $^{\mathrm{a}}$ & 17.4 & 17.6 & 52.1 \\
\hline Ash & 4.8 & 0.9 & 14.0 \\
\hline \multicolumn{4}{|l|}{ Ultimate analysis, wt. $\%$ dry basis } \\
\hline $\mathrm{C}$ & 46.6 & 45.4 & 61.8 \\
\hline $\mathrm{H}$ & 6.4 & 6.3 & 5.6 \\
\hline $\mathrm{N}$ & 0.6 & 0.4 & 2.7 \\
\hline $\mathrm{S}$ & - & - & 1.5 \\
\hline $\mathrm{O}^{\mathrm{a}}$ & 46.4 & 47.9 & 28.5 \\
\hline \multicolumn{4}{|l|}{ Inorganic species, wt.\% dry basis } \\
\hline $\mathrm{Si}$ & 4.60 & 0.36 & 33.3 \\
\hline $\mathrm{Al}$ & 1.76 & 0.09 & 12.9 \\
\hline $\mathrm{Fe}$ & 7.95 & 1.41 & 22.3 \\
\hline $\mathrm{Ca}$ & 26.4 & 52.1 & 1.91 \\
\hline $\mathrm{Mg}$ & 1.23 & 0.13 & 1.73 \\
\hline $\mathrm{Na}$ & - & - & - \\
\hline $\mathrm{K}$ & 48.6 & 41.2 & 3.16 \\
\hline $\mathrm{P}$ & 1.98 & 2.02 & 0.12 \\
\hline $\mathrm{Ti}$ & - & - & 2.87 \\
\hline $\mathrm{Cl}$ & 4.46 & 0.34 & - \\
\hline $\mathrm{S}$ & 2.37 & 0.46 & 19.1 \\
\hline High heating value, $\mathrm{MJ} \mathrm{kg}^{-1 \mathrm{~b}}$ & 18.6 & 18.0 & 27.8 \\
\hline
\end{tabular}

Particles were collected at the outlet of the drop tube furnace using a collection system that consisted of a 3-stage stack impactor (Tecora MSSI PM10-2.5 Multistage Stack Impactor) fitted with $47 \mathrm{~mm}$ quartz microfiber filters and a vacuum pump (Tecora Bravo Plus). Quartz filters were heat treated before sampling, according to the ASTM standard for coal ashing (D3174-12). Sampling was performed for a duration of 5-10 min, and the experiments demonstrated a good repeatability (see $98 \%$ confidence interval error bars in Figures 2 and 4). Collected particles were categorized in the sizes PM>10, PM2.510, and PM2.5 (PM>10 results are not presented herein). The burnout was determined for selected samples ashed in a muffle furnace in compliance with the ASTM standard D3174-12 [18] for coal and ASTM E1755-01 [19] for biomass, to determine the ash weight fraction. Subsequently, the particle burnout, $\Psi$, was calculated in accordance with the procedure in the standard CEN/TS 14775 as follows.

$$
\psi=\frac{1-\frac{\omega_{\mathrm{f}}}{\omega_{\mathrm{x}}}}{1-\omega_{\mathrm{f}}}
$$

In this equation, $\omega_{\mathrm{f}}$ represents the ash weight fraction in the input fuel, and $\omega_{\mathrm{x}}$ is the ash weight fraction in the collected sample. Burnout was above $95 \%$ for all fuels. 


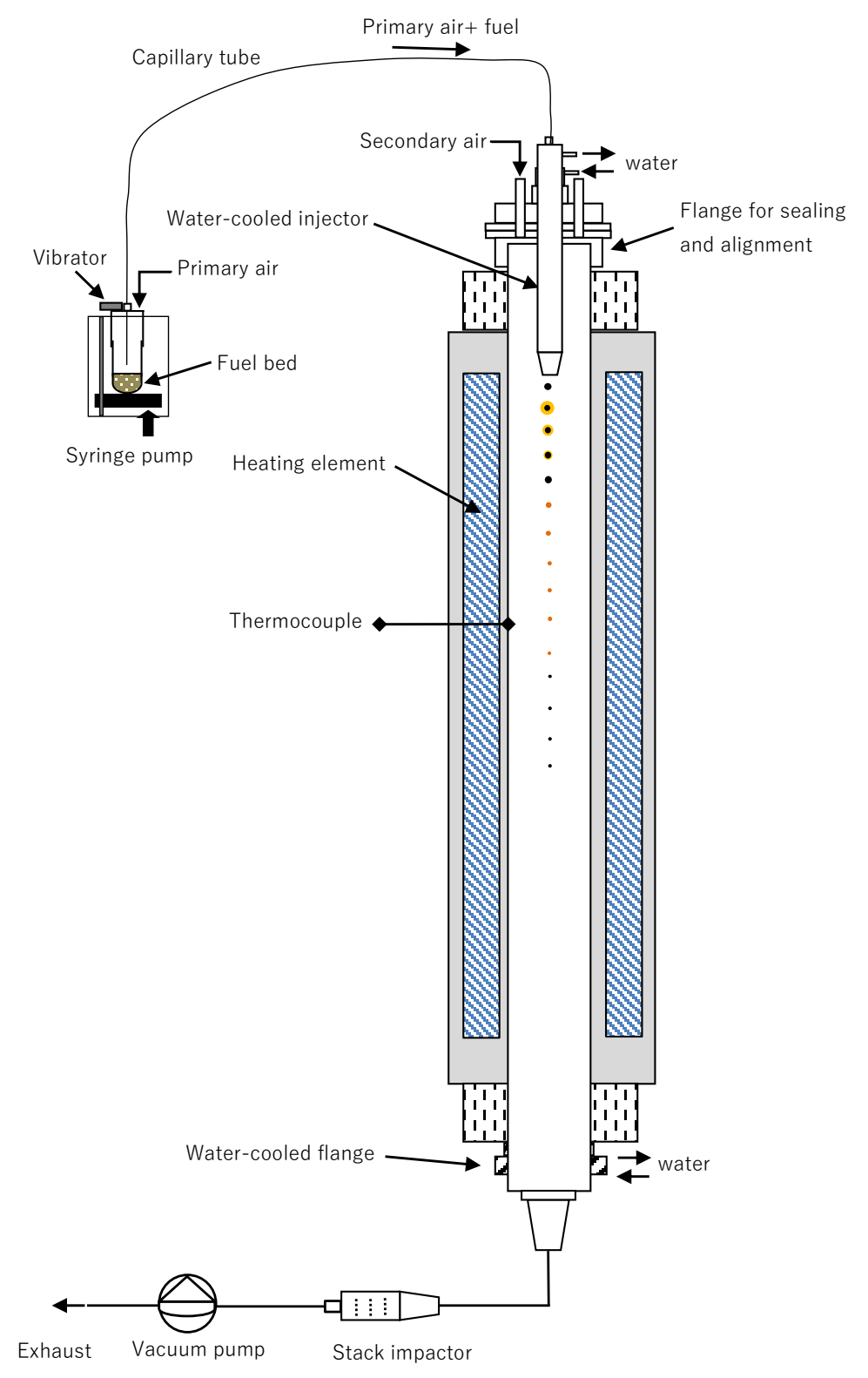

Figure 1. Schematic drawing of the drop tube furnace, feeding system, and collection unit

\section{RESULTS AND DISCUSSION}

\subsection{Fuel Effect on PM Formation}

The fuel type is known to have a strong effect on particulate matter formation [10,13-15]. In the present study, two biomass fuels and a lignite coal are compared in terms of submicron (PM2.5), PM2.5-10, and PM10 concentrations. All PM results are presented in Figure 2, and PM2.5 values are additionally presented in different basis in Table 2 to facilitate comparison with literature.

The concentration of PM2.5 was highest for TL ( $286 \mathrm{mg} / \mathrm{g}$ ash in fuel fed), followed by AS ( $214 \mathrm{mg} / \mathrm{g}$ ) and OR (176 mg/g). PM2.5 for TL was higher ( $40 \mathrm{mg} / \mathrm{g}$ fuel fed) than the value found by Kazanç and Levendis [20] ( 8 mg/g fuel fed) for a lignite coal from Texas (US). Similarly for PM10, Wen et al. [10] measured $\sim 70 \mathrm{mg} / \mathrm{g}$ ash in fuel fed for a lignite coal, whereas herein the PM10 of TL was significantly 
higher (435 mg/g ash in fuel fed). According to Wen et al. [10], there are two competing processes ruling the PM1-10 formation: mineral matter coalescence, and char fragmentation. The TL investigated has been observed in another work by the author [21] to undergo mild fragmentation under similar conditions; furthermore, in the same work [21] char combustion temperatures of $\sim 1500{ }^{\circ} \mathrm{C}$ were measured and albeit sufficient for the melting of $\mathrm{Fe}_{2} \mathrm{O}_{3}$ (melting temperature of $1565^{\circ} \mathrm{C}$ ), are insufficient for the melting of $\mathrm{SiO}_{2}$ (melting temperature of $1710^{\circ} \mathrm{C}$ ). The results obtained suggest that PM10 formation for TL was determined by char fragmentation.

PM2.5 values for OR and AS (see Table 2) were found to be in between the values reported by Ruscio et al. [22] for olive residue ( $26 \mathrm{mg} / \mathrm{g}$ fuel) and corn residue $(\sim 3 \mathrm{mg} / \mathrm{g}$ fuel). TL exhibited a higher PM2.5 than that of OR and AS by 25-40\% (see Figure 2). The concentration of PM2.5 for biomass is due to the presence of alkali and alkali earth metals that present low vaporization point and tend to form particulate matter through the vaporization-condensation mechanism.

For PM2.5-10 the relationship between TL and OR is maintained, i.e. higher PM2.5-10 for TL, but not for TL and AS. Almond shell had PM2.5-10 of $187 \mathrm{mg} / \mathrm{g}$ of ash in fuel fed, whereas TL had $149 \mathrm{mg} / \mathrm{g}$ of ash in fuel fed. Almond shell had PM2.5-10 of $187 \mathrm{mg} / \mathrm{g}$ of ash in fuel fed, whereas TL had $149 \mathrm{mg} / \mathrm{g}$ of ash in fuel fed. In fact, PM2.5-10 for AS was \% 70 higher than that of OR. As observed by the author in another study [23], the interaction between aluminosilicates from lignite (33 wt.\% of Si and $13 \mathrm{wt} . \%$ of $\mathrm{Al}$, in ash) and calcium from almond shell (52 wt.\% of $\mathrm{Ca}$ in ash) forms large gehlenite compounds which contribute to PM2.5-10. Due to the contribution of PM2.5-10 of AS, PM10 was similar to the value of TL (401 and $435 \mathrm{mg} / \mathrm{g}$ ash in fuel, respectively). Moreover, OR showed the lowest values of PM10 among the three fuels $(233 \mathrm{mg} / \mathrm{g}$ ash in fuel fed).

It should be noted that due to the considerably different ash content of these two fuels (cf. Table 1), if the same PM2.5 emission was taken in fuel fed basis, the tendency would be inverted and coal PM2.5 would be greater than that of biomass ( $16 \mathrm{vs} 9 \mathrm{mg} / \mathrm{g}$ fuel). This means that although the PM2.5 emission is lower for biomass; the lower ash content of biomass fuels also plays an important role and needs to be considered for biomass - coal co-firing applications.

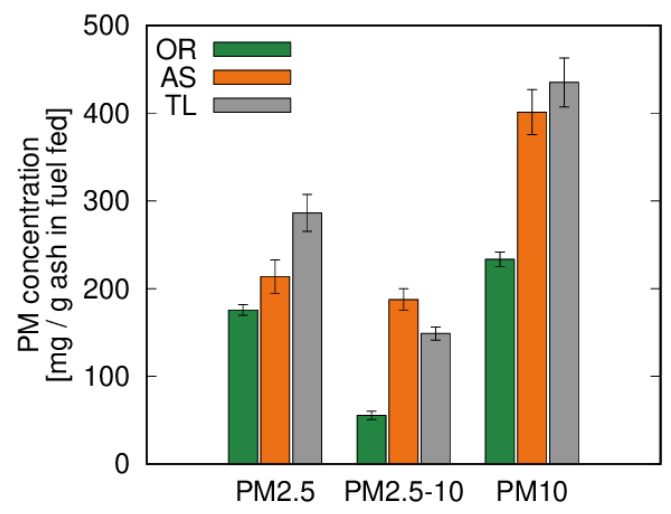

Figure 2. Particulate matter values of all neat fuels (OR - olive residue; AS - almond shell; TL - Tunçbilek lignite). All fuels $<125 \mu \mathrm{m}$. Vertical bars represent $98 \%$ confidence interval statistical error.

Table 2. PM2.5 concentration in different basis for OR, AS, and TL (all <125 $\mu \mathrm{m}$ )

\begin{tabular}{llll}
\hline concentration (basis) & OR & AS & TL \\
\hline${\text { mg per } \mathrm{m}^{3} \text { of air }}_{\text {mg per g ash in fuel input }}^{60}$ & 176 & 50 & 330 \\
mg per g fuel input & 9 & 214 & 286 \\
\hline
\end{tabular}




\subsection{Effect of particle size on PM formation}

The effect of the particle size on PM formation was evaluated from comparison of two particle sizes of OR, specifically $<125 \mu \mathrm{m}$ and 212-300 $\mu \mathrm{m}$. The results are presented in Fig. 3.

Particulate matter formation was lower for all ranges when using larger size particles. Large-size OR presented PM2.5 lower by 11\%, and PM2.5-10 was 16\% lower for small size OR. This illustrated the dependence of PM formation on the particle size. A likely explanation is the higher thermal inertia of the large particles that lowered the particle temperature during combustion and thus reducing the vaporization rate. Following the tendency of PM2.5 and PM2.5-10, PM10 underwent a reduction of $13 \%$.

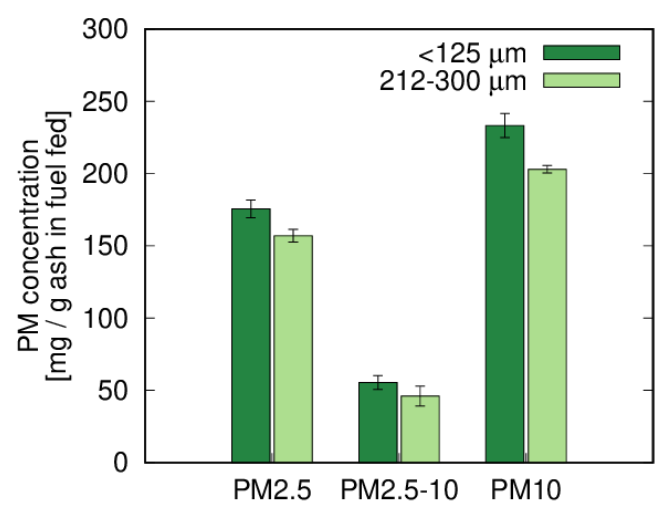

Figure 3. Particulate matter values of OR for two different size cuts $(<125 \mu \mathrm{m}$ and 212-300 $\mu \mathrm{m})$. Vertical bars represent $98 \%$ confidence interval statistical error.

\subsection{Effect of co-Combustion on PM Formation}

Since OR showed lower PM emissions among the two biomass fuels, biomass-coal co-firing trials were conducted for OR-TL blends. Both fuels were screened to $<125 \mu \mathrm{m}$ and mechanically blended. Particulate matter concentration results are presented in Fig. 4. For 50-50 blends, PM2.5 resembled that of OR. In concentration basis (mg of PM per $\mathrm{m}^{3}$ of air), PM2.5 of the blend $\left(124 \mathrm{mg} / \mathrm{m}^{3}\right)$ was between OR $(59.8$ $\left.\mathrm{mg} / \mathrm{m}^{3}\right)$ and TL $\left(329 \mathrm{mg} / \mathrm{m}^{3}\right)$. Moreover, PM2.5-10 of the same blend $(166 \mathrm{mg} / \mathrm{g}$ ash in fuel fed) resembled the value of neat TL (149 mg/g ash in fuel fed) and was clearly above OR (56 mg/g ash in fuel fed).

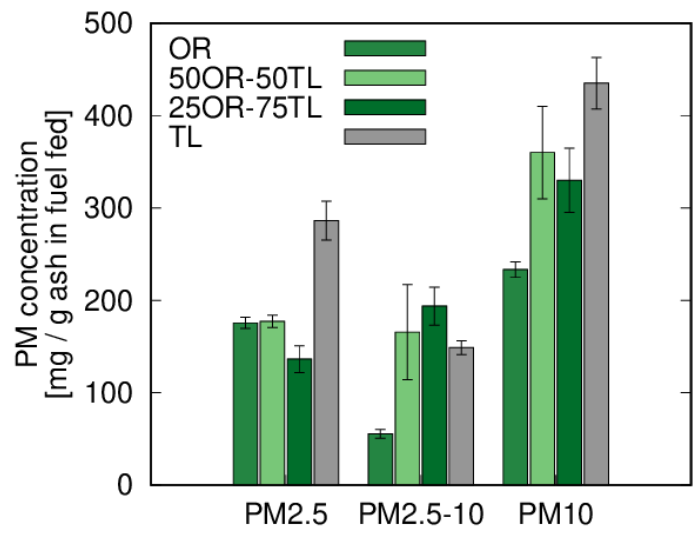

Figure 4. Particulate matter concentration for OR-TL blends. All fuels $<125 \mu \mathrm{m}$. Neat fuels are presented for comparison purposes. Vertical bars represent $98 \%$ confidence interval statistical error.

In summary, 25OR-75TL blends presented lower values of PM2.5 and PM10. As observed by Zellagui et al. [5], ratios of $25 \mathrm{wt} . \%$ of woody biomass in coal minimized submicron PM formation, whereas 
values of $50 \mathrm{wt} . \%$ or $75 \mathrm{wt} . \%$ of biomass were closer to those of the neat biomass. The same trend was observed herein for OR-TL blends. Therefore, ratios of lower amount of biomass ought to be used in future investigation. Moreover, chemical analysis of the PM is necessary to infer on the mechanisms responsible for the high submicron and supermicron particles collected for the blends.

\section{CONCLUSIONS}

This study investigated the particulate matter (PM) formation during co-combustion of an abundant Turkish agricultural residue (olive residue - OR) with a Turkish lignite (Tunçbilek lignite - TL) currently used for power generation. Co-combustion trials were conducted at high temperature and high heating rate using a drop tube furnace. PM was categorised into PM2.5; PM2.5-10; and PM10. The main conclusions of this study can be summarized as follows:

- PM2.5 emission was lowest for olive residue (176 mg/g ash in fuel fed), followed by almond shell (214 mg/g ash in fuel fed) and Tunçbilek lignite (286 mg/g ash in fuel fed).

- PM10 emission was particularly low for olive residue ( $200 \mathrm{mg} / \mathrm{g}$ ash in fuel fed), whereas almond shell and Tunçbilek lignite showed similar values ( $400 \mathrm{mg} / \mathrm{g}$ ash in fuel fed).

- Particle size of olive residue did not have a significant effect on PM formation. This result is relevant since biomass-coal fired stations typically use biomass in particle sizes above those of coal. The results obtained herein suggest that the PM formation would not be significantly affected by the size of biomass. However, co-combustion trials using large-size biomass need to be conducted to ascertain this conclusion.

- Blends of OR-TL in 25-75 ratio showed lower values of both PM2.5 and PM10 as compared with 5050 blends of the same fuels. This has practical implications in the sense that the equipment used to capture PM from lignite combustion can also be used for biomass-lignite co-firing since the share of PM2.5 is always lower for the blends.

\section{ACKNOWLEDGEMENTS}

This work was supported by TÜBİTAK 3501 Career Award No. 214M332.

\section{REFERENCES}

[1] International Energy Agency (IEA). Energy Policies of IEA Countries: Turkey, 2016 Review 2016.

[2] Mills S. Prospects for coal and clean coal technologies in Turkey. July 2014.

[3] IARC. IARC Scientific Publication No. 161: air pollution and cancer. n.d. http://www.iarc.fr/en/publications/books/sp161/index.php (accessed February 26, 2018).

[4] Al-Mansour F, Zuwala J. An evaluation of biomass co-firing in Europe. Biomass and Bioenergy 2010; 34:620-9. doi:10.1016/j.biombioe.2010.01.004.

[5] Zellagui S, Trouvé G, Schönnenbeck C, Zouaoui-Mahzoul N, Brilhac J. Parametric study on the particulate matter emissions during solid fuel combustion in a drop tube furnace. Fuel 2017; 189:358-68.

[6] Seames WS. An initial study of the fine fragmentation fly ash particle mode generated during pulverized coal combustion. Fuel Process Technol 2003;81:109-25. doi:10.1016/S03783820(03)00006-7. 
[7] Wolski N, Maier J, Hein KRG. Fine particle formation from co-combustion of sewage sludge and bituminous coal. Fuel Process Technol 2004; 85:673-86. doi:10.1016/j.fuproc.2003.11.024.

[8] Xu M, Yu D, Yao H, Liu X, Qiao Y. Coal combustion-generated aerosols: Formation and properties. Proc Combust Inst 2011; 33:1681-97. doi:10.1016/j.proci.2010.09.014.

[9] Sippula O, Hokkinen J, Puustinen H, Yli-Pirilä P, Jokiniemi J. Comparison of particle emissions from small heavy fuel oil and wood-fired boilers. Atmos Environ 2009; 43:4855-64. doi:10.1016/J.ATMOSENV.2009.07.022.

[10] Wen C, Gao X, Yu Y, Wu J, Xu M, Wu H. Emission of inorganic PM10from included mineral matter during the combustion of pulverized coals of various ranks. Fuel 2015; 140:526-30. doi:10.1016/j.fuel.2014.09.114

[11] Linak WP, Miller CA, Seames WS, Wendt JOL, Ishinomori T, Endo Y, et al. On trimodal particle size distributions in fly ash from pulverized-coal combustion. Proc Combust Inst 2002; 29:441-7. doi:10.1016/S1540-7489(02)80058-X.

[12] Fix G, Seames W, Mann M, Benson S, Miller D. The effect of combustion temperature on coal ash fine-fragmentation mode formation mechanisms. Fuel 2013; 113:140-7. doi:10.1016/j.fuel.2013.05.096.

[13] Zhang L, Ninomiya Y. Emission of suspended PM10from laboratory-scale coal combustion and its correlation with coal mineral properties. Fuel 2006; 85:194-203. doi:10.1016/j.fuel.2005.03.034.

[14] Kazanc F, Levendis YA, Maffei T. Chemical Composition of Submicrometer Particulate Matter (PM1) Emitted from Combustion of Coals of Various Ranks in $\mathrm{O}_{2} / \mathrm{N}_{2}$ and $\mathrm{O}_{2} / \mathrm{CO}_{2}$ Environments. Energy \& Fuels 2013;27:4984-98.

[15] Feng C, Gao X, Wu H. Emission of particulate matter during the combustion of bio-oil and its fractions under air and oxyfuel conditions. Proc Combust Inst 2017; 36:4061-8. doi:10.1016/J.PROCI.2016.08.053.

[16] Friedl A, Padouvas E, Rotter H, Varmuza K. Prediction of heating values of biomass fuel from elemental composition. Anal Chim Acta 2005; 544:191-8. doi:10.1016/j.aca.2005.01.041.

[17] Majumder AK, Jain R, Banerjee P, Barnwal JP. Development of a new proximate analysis based correlation to predict calorific value of coal. Fuel 2008; 87:3077-81. doi:10.1016/j.fuel.2008.04.008.

[18] ASTM. Standard Test Method for Ash in the Analysis Sample of Coal and Coke from Coal D317412. ASTM Int 2011:1-6. doi:10.1520/D3174-12.2.

[19] ASTM. Standard test method for ash in biomass E1755 - 01. ASTM 2015; 44:153-161. doi:10.1520/E1755-01R15.2.

[20] Kazanc F, Levendis YA. Physical Properties of Particulate Matter Emitted from Combustion of Coals of Various Ranks in $\mathrm{O}_{2} / \mathrm{N}_{2}$ and $\mathrm{O}_{2} / \mathrm{CO}_{2}$ Environments. Energy \& Fuels 2012; 26:7127-39. doi:10.1021/ef301087r.

[21] Magalhães D, Panahi A, Kazanç F, Levendis YA. Comparison of single particle combustion behaviours of raw and torrefied biomass with Turkish lignites. Fuel 2019; 241:1085-94. doi:10.1016/j.fuel.2018.12.124. 
Kazanç Özerinç / Eskişehir Tech. Univ. J. of Sci. and Technology A-Appl. Sci. and Eng. 20 (3) - 2019

[22] Amanda Ruscio; Feyza Kazanc; and Yiannis A. Levendis. Characterization of Particulate Matter Emitted from Combustion of Various Biomasses in $\mathrm{O}_{2} / \mathrm{N}_{2}$ and $\mathrm{O}_{2} / \mathrm{CO}_{2}$ Environments. Energy \& Fuels 2013; 28:685-96. doi:dx.doi.org/10.1021/ef401796w.

[23] Magalhaes D, Riaza J, Kazanç F. A study on the reactivity of various chars from Turkish fuels obtained at high heating rates. Fuel Process Technol 2019; 185:91-9. doi:10.1016/j.fuproc.2018.12.005. 